\title{
「生物学のデータと可視化」特集号についで
}

\author{
西田 孝三**

\section{Biological Data and Visualization}

Kozo NisHidA

生物学に関連するデー夕の量と複雑さは急速に増大し ており，その可視化のための技術はますます重要になっ ている，本特集号では生物学ではどのようなデータが増 えているのか, どのように複雑なのか, どのような可視 化技術が求められているのかをソフトウェア開発を行う 研究者が集まり, 広範な生物学研究分野に対して紹介す る.

今回の特集号では生物学における様々なネットワーク データ,ゲノムの新しいデータ表現, 生命現象の時空間 動態デー夕を可視化する手法を開発されている方々 4 名 に執筆をお願いし，また編集委員も執筆に加わり，6編 の可視化手法について紹介する.

大野圭一朗氏（カリフォルニア大学サンディエゴ校） には遺伝子機能に関するオントロジーの階層構造データ とそれに関連する分子間相互作用ネットワークの統合可 視化ダッシュボード HiView についてご紹介いただいた. 生命科学における異種デー夕の統合可視化ウェブアプリ ケーション, 特にそれをUIコンポーネントの集合とし て設計・実装している例はまだ多くは無い. HiView で はどのように可視化とインタラクションのデザインが行 われているか, またアプリケーションの設計と実装が行 われているかを大野氏にはご紹介いただいた。

担当編集の西田孝三（理化学研究所）は代謝経路に代 表される生化学反応ネットワーク（パスウェイ）とそれ に関するデータのためのダッシュボード用可視化コン ポーネントDash-Pathwayを紹介した. 大野氏と同様 にネットワーク可視化とダッシュボードに関する話題で あるが，パスウェイにはオントロジーの階層構造や分子 間相互作用ネットワーク一般とは異なる独自の可視化に 関する難しさがある.また Dash-Pathway はダッシュ ボードではなくダッシュボードフレームワークのコン ポーネントという形での実装である。これら大野氏との 差異の説明に加え, Dash-Pathway の応用例も紹介した. 横山稔之氏 (東京大学) には複数の個体のゲノムをグ
ラフ構造によって表現するグラフゲノムのための可視化 ツール MoMI-G についてご紹介いただいた.グラフゲ ノムの背景や定義，またそのブラウザである MoMI-G の設計と機能, そして遺伝性疾患やがんの原因となる例 もあるゲノムの構造多型をその可視化対象の代表として ご紹介いただいた。

片山俊明氏（ライフサイエンス統合データベースセン ター）には RDF・SPARQL を使用して生命科学におけ るリンクトデータを処理するッール SPARQList に加え, その結果を可視化する d 3sparql.js やウェブアプリケー ション用コンポーネントフレームワーク TogoStanza に ついてご紹介いただいた．またその応用例としてゲノム データベース TogoGenome についてもご紹介いただい た.

京田耕司氏（理化学研究所）には顕微鏡画像に代表さ れる生命現象の時空間動態データの定量フォーマット BDML やその可視化ツールについてご紹介いただいた. このような定量データや元画像，またその他のデータを 統合した分析や可視化はバイオイメージ・インフォマ ティクスと呼ばれ近年急速に発展している．同じく担当 編集の夏川浩明氏（京都大学）には前述のバイオイメー ジ・インフォマティクスで定量化された画像の特徴量に 基づくネットワークと遺伝子に関する情報のネットワー クを統合し, 可視化を行うデータ探索システム PheGeNetについてご紹介いただいた。お二人の紹介は バイオイメージ・インフォマティクスのための「定量 化」「定量データ分析結果の探索のための可視化」で地 続きの関係にある。続けてお読みいただけると幸いであ る.

可視化研究者の皆様に本特集で紹介した可視化手法に 対してのフィードバックを頂き，相互の研究の発展につ ながる情報交換が行えれば幸いである，最後にご執筆を ご快諾いただいた執筆者の皆様に深く感謝申し上げる.

* 原稿受付 2019 年 11 月 19 日

** 理化学研究所 生命機能科学研究センター （广 565-0874 大阪府吹田市古江台 6-2-3, E-mail : knishida@riken.jp) 